\title{
Identifikasi Lokasi dan Performa Fisik Kambing Perah di Desa Mranggen Kecamatan Srumbung Kabupaten Magelang Provinsi Jawa Tengah
}

\author{
(Identification of Location and Physical Performance of Dairy Goats in Mranggen Village, Srumbung \\ District, Magelang Regency, Central Java Province)
}

Bayu Fajar Ariyanto ${ }^{1}$, Widitya Tri Nugraha ${ }^{1 *}$, dan Danes Suhendra ${ }^{1}$

${ }^{1}$ Program Studi Peternakan, Fakultas Pertanian, Universitas Tidar, Jl. Kapten Suparman No.39, Potrobangsan, Kec. Magelang Utara, Kota Magelang, Jawa Tengah

*Penulis Korespondensi: (widityatri.nugraha@untidar.ac.id)

Dikirim (received): 10 Oktober 2021; dinyatakan diterima (accepted): 29 Oktober 2021; terbit (published): 15 November2021. Artikel ini dipublikasi secara daring pada https://ejournal.unib.ac.id/index.php/buletin_pt/index

\begin{abstract}
One of the sub-districts in Magelang Regency, Central Java with a fairly high goat population is in Srumbung District with a goat population of around 1,344 heads. The total population includes beef goats and dairy goats. Until now, there is no supporting information regarding the location and condition of dairy goats in Srumbung District, especially in Mranggen Village. This study aims to identify the location of the farm and the physical performance of dairy goats in Mranggen Village. Sampling of the research object used purposive sampling. The criteria for the sample of dairy goats used in this study were female dairy goats with the age of over 1 year as many as 48 heads. The data obtained were analyzed descriptively. The results showed that the location of the dairy goat farm was at an altitude of +539 masl, a temperature of $24.50 \mathrm{C}$, humidity of $70.7 \%$ and THI of 73.43 . There are two types of dairy goats, Peranakan Ettawah (PE) and Sapera goats with physical performance observed for head length, head width, ear length, gumba height, ear width, chest circumference and body length. The conclusion of the research that Mranggen Village has a supportive environmental condition for the maintenance of dairy goats. The altitude, temperature and humidity as well as THI are in the comfort zone for livestock to live. The body size of the PE goat is included in the SNI standard, namely body length, chest circumference and ear length, except for shoulder height which does not meet the minimum requirements of SNI. Meanwhile, the physical performance of the Sapera goat has almost the same body and head size as the $\mathrm{PE}$ goat, but the ears are smaller and shorter.
\end{abstract}

Key words: profile, physical, Peranakan Etawa, Sapera

\begin{abstract}
ABSTRAK
Salah satu kecamatan di Kabupaten Magelang, Jawa Tengah dengan populasi kambing cukup tinggi berada di Kecamatan Srumbung dengan populasi kambing sekitar 1.344 ekor. Jumlah populasi tersebut termasuk kambing potong dan kambing perah. Hingga saat ini belum ada informasi pendukung terkait tentang lokasi dan kondisi ternak kambing perah di Kecamatan Srumbung, khususnya di Desa Mranggen. Penelitian ini bertujuan untuk mengidentifikasi lokasi peternakan dan performa fisik kambing perah di Desa Mranggen. Pengambilan sampel objek penelitian menggunakan purposive sampling. Kriteria sampel kambing perah yang digunakan dalam penelitian ini yaitu kambing perah betina dengan umur di atas 1 tahun sebanyak 48 ekor. Data yang diperoleh dianalisis secara deskriptif. Didapatkan hasil bahwa lokasi peternakan kambing perah berada pada ketinggian $+539 \mathrm{mdpl}$, suhu 24,5 oC, kelembapan $70.7 \%$ dan $\mathrm{THI} 73,43$. Terdapat dua jenis kambing perah yaitu kambing Peranakan Ettawah (PE) dan Sapera dengan performa fisik yang diamati panjang kepala, lebar kepala, panjang telinga, tinggi gumba, lebar telinga, lingkar dada dan panjang badan. Kesimpulan dari penelitian Desa Mranggen memiliki kondisi lingkungan yang mendukung untuk pemeliharaan kambing perah. Ketinggian tempat, suhu dan kelembapan serta THI berada pada zona nyaman untuk ternak (comfort zone) hidup. Ukuran tubuh kambing PE masuk dalam standar Stdanadr Nasional Indonesia (SNI) yaitu panjang badan, lingkar dada dan panjang telinga kecuali tinggi pundak yang belum sesuai syarat minimal SNI. Sedangkan performa fisik kambing Sapera memiliki ukuran tubuh dan kepala yang hampir sama seperti kambing PE namun untuk ukuran telinga lebih kecil dan pendek.
\end{abstract}

Kata kunci: performa, fisik, peranakan Etawa, Sapera 


\section{PENDAHULUAN}

Kambing merupakan salah satu ternak yang cukup disenangi untuk diternakkan. Hal ini karena dalam pemeliharaannya cukup mudah. Kambing memiliki ukuran tubuh yang kecil sehingga tidak terlalu membutuhkan tempat yang besar dalam pemeliharaannya seperti sapi ataupun kerbau (Nugraha, 2021). Kambing perah menjadi salah satu komoditi ternak yang saat ini mulai dikembangkan di Kabupaten Magelang, Provinsi Jawa Tengah. Pengembangannya masih tergolong lambat, hal ini akibat masih banyaknya kendala dalam pemeliharaannya. Beberapa permasalahan yang dihadapi dalam pengembangan ternak kambing antara lain keterbatasan lahan, tenaga kerja, sumber daya, maupun pemahaman peternak mengenai manajemen pemeliharaan (Miftahudin, 2020).

Menurut Badan Pusat Statistik Kabupaten Magelang (2021), populasi ternak kambing di Kabupaten Magelang sekitar 32.504 ekor dan salah satu kecamatan dengan populasi kambing cukup tinggi berada di Kecamatan Srumbung dengan populasi kambing sekitar 1.344 ekor. Jumlah populasi tersebut termasuk kambing potong dan kambing perah. Hal ini tentunya membuat potensi pengembangan peternakan kambing di Kabupaten Magelang terbuka lebar. Hingga saat ini belum ada informasi pendukung terkait tentang lokasi dan kondisi ternak kambing perah di Kecamatan Srumbung, khususnya di Desa Mranggen yang merupakan desa wisata dengan unggulan kambing perahnya (Muhajir dan Muchlis, 2020).

Salah satu indikator untuk mengetahui potensi pengembangan kambing perah adalah performa fisik ternak. Performa fisik ternak yang baik mengindikasikan bahwa ternak tersebut akan memiliki produktivitas yang baik pula. Sehingga potensi pengembangan peternakan kambing akan semakin tinggi. Performa fisik yang biasanya dijadikan dalam penilaian performa ternak adalah panjang, lingkar dan tinggi badan (Christi et al., 2019). Identifikasi performa ternak ini menjadi data yang penting untuk diketahui, sebagai acuan dalam pengembangan peternakan tersebut.

Berdasarkan penjelasan di atas maka penting dilakukan penelitian mengenai kondisi lokasi dan performa fisik kambing perah di Desa Mranggen, Kecamatan Srumbung Kabupaten Magelang. Data-data mengenai lokasi seperti ketinggian tempat, suhu dan kelembaban serta ukuran tubuh ternak meliputi panjang kepala, lebar kepala, panjang telinga, tinggi gumba, lebar telinga, lingkar dada dan panjang badan kambing perah menjadi data yang akan diambil dalam penelitian ini. Sehingga berdasarkan data tersebut dapat diketahui produktivitas ternak berdasarkan performa fisik, dan dapat diketahui potensi pengembangannya.

\section{BAHAN DAN METODE}

\section{Waktu dan Tempat}

Penelitian ini dilakukan pada bulan FebruariApril 2021 di Desa Mranggen, Kecamatan Srumbung, Kabupaten Magelang. Metode pengambilan data yang dilakukan yaitu pengamatan dan pengukuran ukuran tubuh ternak secara langsung di lokasi penelitian. Data lokasi seperti ketinggian tempat, suhu dan kelembapan serta ukuran ternak yang diambil dalam penelitian meliputi panjang kepala, lebar kepala, panjang telinga, tinggi gumba, lebar telinga, lingkar dada dan panjang badan.

\section{Alat dan Bahan}

Objek penelitian yang digunakan adalah kambing perah betina. Pengambilan sampel objek penelitian menggunakan purposive sampling. Kriteria sampel kambing perah yang digunakan dalam penelitian ini yaitu kambing perah betina dengan umur di atas 1 tahun sebanyak 48 ekor. Alat yang digunakan untuk pengukuran dan pendataan ternak meliputi thermohygrometer, smartphone, mistar ukur, pita ukur, timbangan, tali, dan alat tulis.

\section{Analisis Data}

Data yang diperoleh disajikan dalam bentuk tabel dan gambar. Data-data tersebut dianalisis secara deskriptif lalu dibandingkan dengan pustaka.

\section{HASIL DAN PEMBAHASAN}

\section{Gambaran Umum Lokasi Penelitian}

Desa Mranggen, Kecamatan Srumbung merupakan daerah yang berada di bawah lereng Gunung Merapi (Gambar 1). Desa Mranggen berada pada lokasi yang sangat baik dalam pengembangan ternak perah. Berdasarkan hasil pengamatan ketinggian tempat, suhu, kelembapan dan temperature humidity index (THI) lokasi ini berada pada lokasi yang nyaman untuk ternak tumbuh, selain itu ketersediaan pakan hijauan akan melimpah karena kondisi lingkungan yang mendukung. Berdasarkan hasil 
pengamatan ketinggian, suhu, kelembaban dan THI di Desa Mranggen dapat dilihat pada Tabel 1.

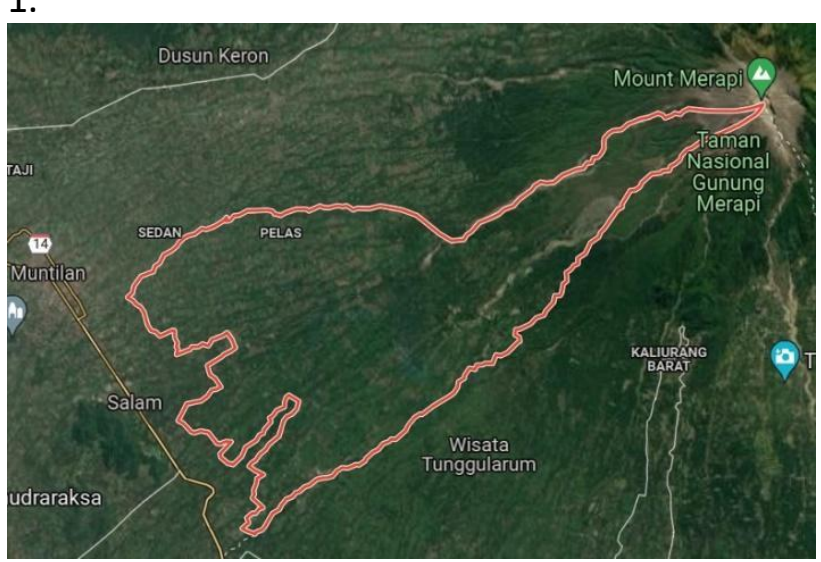

Gambar 1. Peta Geografi Kecamatan Srumbung Kabupaten Magelang

Sumber:https://www.google.com/maps/place/Srumbung)

Ketinggian tempat berpengaruh pada suhu mikro dan kelembaban kandang. Dalam pemeliharaan kambing perah suhu dan kelembaban menjadi salah satu indikator yang sangat penting karena akan berpengaruh terhadap kondisi fisiologi ternak. Semakin tinggi lokasi peternakan maka pertumbuhan yang dialami ternak akan semakin baik (Batubara et al., 2016). Ketinggian tempat akan berpengaruh terhadap ketersediaan pakan seperti legume yang merupakan pakan utama untuk kambing perah. Selain itu lokasi ini berada pada lereng Gunung Merapi yang merupakan salah satu gunung api yang masih aktif di Indonesia. Keberadaan gunung berapi aktif ini akan berpengaruh terhadap kesuburan tanah. Prawiradiputra (2011) menyatakan bahwa lahan di lereng gunung berapi merupakan tanah vulkanik. Tanah ini umumnya merupakan lahan yang subur karena mengandung unsur hara yang tinggi.

Berdasarkan Tabel 1 kondisi suhu, kelembaban dan THI lokasi tersebut berada pada kondisi yang nyaman untuk ternak hidup. Menurut Smith dan Mangkuwidjojo (1988), suhu nyaman bagi kambing perah yaitu sekitar $18^{\circ} \mathrm{C}$ sampai $30^{\circ} \mathrm{C}$. Hasil tersebut juga sesuai dengan pendapat Broom dan Fraser (2015), yang menyebutkan bahwa batas kritis pada suhu terendah untuk kambing perah $220 \mathrm{C}$ sedangkan untuk batas kritis suhu tertinggi yaitu $35^{\circ} \mathrm{C}$. Hamdan et al. (2018), yang menyatakan bahwa nilai THI normal pada kambing perah yaitu $<74$, dengan standar lain 75-78 kondisi siaga, 79-83 bahaya dan $>84$ sangat berbahaya.
Selain itu, menurut Moran dan Chamberlain (2017) pengelompokan THI pada sapi perah dibagi dalam lima zona yaitu $\mathrm{THI}<72$ merupakan zona nyaman, 72-78 menyebabkan stres ringan, 78-89 stres berat, 89-98 stres berat sangat parah, dan $>98$ menyebabkan kematian.

Tabel 1. Kondisi lokasi di Desa Mranggen, Kecamatan Srumbung.

\begin{tabular}{ll}
\hline \multicolumn{1}{c}{ Parameter } & \multicolumn{1}{c}{ Rata-rata } \\
\hline Ketinggian tempat & $+539 \mathrm{mdpl}$ \\
Suhu & $24,5^{\circ} \mathrm{C}$ \\
Kelembapan & $70.7 \%$ \\
THI & 73,43 \\
\hline
\end{tabular}

Sehingga berdasarkan uraian di atas Desa Mranggen, Kecamatan Srumbung, Kabupaten Magelang memiliki lokasi yang baik untuk pemeliharaan kambing perah. Ketinggian tempat, suhu dan kelembaban serta THI berada pada zona nyaman untuk ternak (comfort zone) hidup

\section{Performa Fisik Ternak Kambing Perah}

Berdasarkan hasil pengamatan yang telah dilakukan jenis kambing perah yang terdapat di Desa Mranggen yaitu kambing Peranakan Ettawah (PE) dan kambing Saanen Peranakan Ettawah atau sering disebut Sapera (Gambar 2). Nugraha (2021) menyampaikan bahwa Kambing Etawah merupakan kambing yang familiar dikenal di Indonesia. Kambing ini merupakan kambing yang berasal dari India yang dikenal dengan kambing Jamunapari. Namun di Indonesia, kambing ini sudah tidak memiliki darah murni, karena sudah disilangkan dengan kambing kacang yang merupakan kambing lokal Indonesia. Sehingga saat ini disebut dengan kambing Peranakan Etawah (PE). Sedangkan kambing Sapera merupakan kambing persilangan antara PE dan Saanen.

Tabel 2. Performa fisik kambing perah di Desa Mranggen

\begin{tabular}{cccccccc}
\hline Jenis & \multicolumn{7}{c}{ Rata-rata } \\
\cline { 2 - 8 } Kambi & PK & LK & PT & LT & LD & PB & TP \\
ng & $(\mathrm{cm})$ & $(\mathrm{cm})$ & $(\mathrm{cm})$ & $\begin{array}{c}(\mathrm{c} \\
(\mathrm{cm})\end{array}$ & $(\mathrm{cm})$ & $(\mathrm{cm})$ \\
& & & & $\mathrm{m})$ & & & \\
\hline PE & 26,0 & 14,8 & 27,7 & 11, & 93,8 & 84,0 & 39,7 \\
& 5 & 5 & 5 & 9 & 5 & 5 & 5 \\
\hline Sapera & 24,8 & 14,8 & 18,2 & 8,6 & 93,8 & 88,9 & 43 \\
& & & & 8 & & 2 & \\
\hline
\end{tabular}

Keterangan: $\mathrm{PK}=$ Panjang Kepala , LK = Lebar Kepala, PT = Panjang Telinga TP = Tinggi Pundak, LT = Lebar Telinga $\mathrm{LD}=$ Lingkar Dada $\mathrm{PB}=$ Panjang Badan 


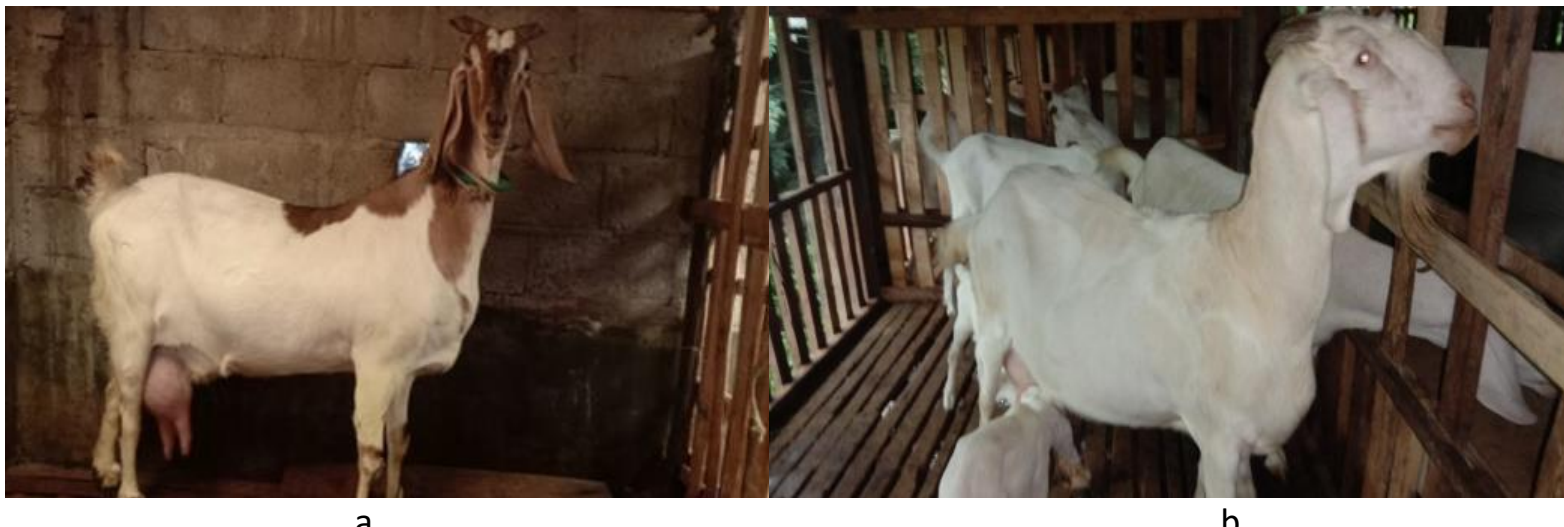

a

b

Gambar 2. a. Kambing PE Betina, b. Kambing Sapera Betina

Perhitungan rata-rata performa fisik kambing perah dalam penelitian ini didasarkan pada kambing dengan umur di atas 1 tahun. Penentuan umur dilakukan dengan estimasi pendugaan umur sesuai berdasarkan kondisi gigi. Hal ini dilakukan karena belum adanya data pencatatan/recording ternak di lokasi penelitian. Sulastri dan Sumadi (2005) menyatakan bahwa umur kambing yang diduga berdasarkan kondisi gigi seri ternyata sesuai dengan umur nyata yang dihitung berdasarkan catatan tanggal lahir.

Hasil pengamatan menunjukan bahwa kambing PE memiliki rata-rata panjang telinga yaitu 26,05 cm sedangkan pada kambing Sapera $24,8 \mathrm{~cm}$. Hingga saat ini belum ada standar nasional yang mengatur kambing perah selain kambing PE dan kambing Kaligesing. Menurut Budisatria et al., (2018), Kambing PE dengan grade $A$ mempunyai panjang telinga $30 \mathrm{~cm}$, dengan grade B $25 \mathrm{~cm}-30 \mathrm{~cm}$ dan grade C dibawah $25 \mathrm{~cm}$.

Penentuan grade kambing perah juga dapat dilihat dari nilai panjang badan dan lingkar dada. Penentuan tersebut dapat mempengaruhi pada nilai penafsiran bobot ternak, semakin tinggi nilai panjang badan dan lingkar dada, maka bobot ternak juga akan semakin tinggi. Menurut Setiawati et al. (2013), pertambahan ukuran lingkar dada akan mengikuti pertumbuhan dan perkembangan jaringan otot pada daerah dada atau tulang rusuk, sedangkan untuk perubahan ukuran panjang badan merupakan cerminan dari pertumbuhan dan perkembangan daerah tulang belakang (Trisnawanto et al., 2012).

Pada hasil pengamatan beberapa kriteria ukuran tubuh kambing PE masuk dalam standar SNI yaitu panjang badan, lingkar dada dan panjang telinga kecuali tinggi pundak yang belum masuk sesuai SNI. Berdasarkan SNI tentang Kambing PE (2015) untuk kambing Peranakan Ettawah umur di atas 1 tahun minimal memiliki tinggi pundak $65 \mathrm{~cm}$, panjang badan $62 \mathrm{~cm}$, lingkar dada $66 \mathrm{~cm}$ dan panjang telinga $26 \mathrm{~cm}$.

Jika dilihat dari performa fisik kambing Sapera memiliki ukuran tubuh dan kepala yang hampir sama seperti kambing PE namun untuk ukuran telinga lebih kecil dan pendek. Hasil tersebut sesuai menjelaskan pernyataan dari Kaleka dan Haryadi (2013), yang menyebutkan bahwa kambing Sapera memiliki postur dan perawakan yang mendekati indukannya yaitu kambing PE. Namun, menurut Anggreini, 2020), eksterior kambing Sapera memiliki karakteristik yang lebih menyerupai dengan kambing Saanen dibanding dengan kambing PE. Kemiripan tersebut mencakup warna bulu yang umumnya putih, muka menyerupai segitiga dengan hidung lurus, dan daun telinga yang terkulai ke bawah dengan bentuk tegak kesamping dan kedepan.

\section{KESIMPULAN}

Berdasarkan hasil dari penelitian dapat disimpulkan bahwa Desa Mranggen, Kecamatan Srumbung, Kabupaten Magelang memiliki kondisi lingkungan yang mendukung untuk pemeliharaan kambing perah. Ketinggian tempat, suhu dan kelembaban serta THI berada pada zona nyaman untuk ternak (comfort zone) hidup. Terdapat dua (2) jenis kambing perah yang dipelihara di lokasi tersebut yaitu kambing PE dan Sapera. Performa fisik ternak kambing tersebut kriteria ukuran tubuh kambing $P E$ masuk dalam standar SNI yaitu panjang badan, lingkar dada dan panjang telinga kecuali tinggi pundak yang belum masuk sesuai syarat minimal SNI. Sedangkan performa fisik kambing Sapera memiliki ukuran tubuh dan kepala yang hampir sama seperti kambing PE namun untuk ukuran telinga lebih kecil dan pendek.

\section{DAFTAR PUSTAKA}

Anggreini, A. 2020. Morfometrik kambing perah 
G1 Sapera betina berdasarkan analisa citra digital. Prosiding Seminar Nasional Teknologi Peternakan dan Veteriner Virtual 2020. Balai Penelitian Ternak, Ciawi. Bogor. Pros.Semnas.TPV-2020-p.347-35.

BPS Kabupaten Magelang. 2021. https://magelangkab.bps.go.id/statictable/2 018/12/11/432/jumlah-rumah-tangga-

usaha-peternakan-menurut-kecamatan-danjenis-ternak-st2013.html. Diakses tanggal 10 Oktober 2021.

Batubara, A., S. Nasution, Subandriyo, I. Inounu, B. Tiesnamurti, dan A. Anggraeni. 2016. Kambing Peranakan Etawa (PE). Badan Penelitian dan Pengembangan Pertanian. Indonesian Agency For Agricultural Research And Development (IAARD) Press: Jakarta.

Broom, D. M. dan A.F. Fraser. 2015. Domestic animal behaviour and welfare. $5^{\text {th }}$ ed. Pp: 110-111, 138-139. Tarxien, Malta: Gutenberg Press.

Budisatria, I.G.S., Panjono, D. Maharani, dan A. Ibrahim. 2018. Kambing Peranakan Etawa. Universitas Gadjah Mada. UGM Press.

Christi, R. F., L.B., Salman, Hermawan dan D. Suharwanti. 2019. Karakteristik ukuran tubuh kambing peranakan ettawa pada periode dara dan laktasi 1 di kelompok P4S Agribisnis Assalam Indihiang Kabupaten Tasikmalaya. Jurnal Sains Peternakan, 7(2), 122-127.

https://doi.org/10.21067/jsp.v7i2.3993.

Hamdan, A., B.P. Purwanto, D.A. Astuti, A. Atabany, dan E. Taufik. 2018. Respons kinerja produksi dan fisiologis kambing Peranakan Ettawa terhadap pemberian pakan tambahan dedak halus pada agroekosistem lahan kering di Kalimantan Selatan. JPPTP. 12 (1): 73-84.

Miftahudin. 2020. Analisis ekonomi Kambing Etawa pola gaduhan: Studi kasus di Desa Sukomulyo, Kecamatan Kajoran, Kabupaten Magelang. Jurnal Paradigma Multidisipliner (JPM) 1(1): 31-41.

Muhajir, M. dan Muchlis, Z 2020. Inovasi teknologi dan pengembangan teknologi informasi dalam pemberdayaan masyarakat pasca Covid-19. Prosiding Semnas PPM 2020. DOI: 10.18196/ppm.32.226.

Nugraha, W.T. 2021. Bangsa-Bangsa Ternak Perah. CV. Pena Persada, Jawa Tengah.

Nugraha, W.T. 2017. Gambaran kondisi wilayah dan jalur tata niaga susu kambing di Kabupaten Sleman. Journal of Livestock Science and Production 1 (1), 24-30

Kaleka dan Haryadi. 2013. Seri Peternakan Modern Kambing Perah, Arcita, Surakarta.

Moran, J., dan P. Chamberlain. 2017. Blueprints for tropical dairy farming : Increasing Domestic Milk Production in Developing Countries . CSIRO Publishing.

Prawiradiputra, B. R. 2011. Tanaman pakan untuk menunjang rehabilitasi peternakan di lereng Gunung Merapi. Wartazoa 21 (4): 171178.

Setiawati, T., P. Sambodho, dan A. Sustiah. 2013. Tampilan bobot badan dan ukuran tubuh kambing dara Peranakan Ettawa akibat pemberian ransum dengan suplementasi urea yang berbeda. J. Anim. Agriculture. 2 (2): 8-14.

Smith, J.B., dan Mangkoewidjojo. 1988, Pemeliharaan, Pembiakan, dan Hewan Percobaan di Daerah Tropis. UI press, Jakarta.

Standar Nasional Indonesia. 2015. Bibit Kambing Bagian - 1 Peranakan Etawa. Badan Standar Nasional. Jakarta.

Trisnawanto, R., Adiwinarti dan W. S. Dilaga. 2012. Hubungan antara ukuran-ukuran tubuh dengan bobot badan Dombos jantan. J. Anim. Agriculture. 1 (1): 653-668.

Unites State Departement of Agriculture USDA. 2000. Egg- grading Manual. Departement of Agriculture, Washington.

Winarno, F. G. 2003. Pangan, Gizi,Teknologi dan Konsumen. Gramedia : Jakarta.

Yamamato T., L. R. Juneja, H. Hatta dan M. Kim. 2007. Hen Eggs: Basic and Appllied Science. Universitas of Alberta, Canada. 